\title{
The Presence of Protein-Bound $\gamma$-Carboxyglutamic Acid in Calcium-Containing Renal Calculi
}

\author{
J. B. Lian, E. L. Prien, JR., M. J. Glimcher, and P. M. Gallop \\ From the Departments of Orthopedic Surgery, Biological Chemistry, and Oral Biology, Harvard \\ Medical School, Harvard School of Dental Medicine; The Children's Hospital Medical Center; \\ and The Medical Services of The Massachusetts General Hospital, Boston, Massachusetts 02115
}

\begin{abstract}
A B S T R A C T The amino acid $\gamma$-carboxyglutamic acid (Gla) is found in four blood-clotting proteins, in a bone protein, in kidney protein, and in the protein present in various ectopic calcifications. This paper reports the presence of Gla in the EDTA-soluble, nondialyzable proteins of calcium-containing renal calculi including calcium oxalate, hydroxyapatite, and mixed stores of apatite and struvite $\left(\mathrm{MgNH}_{4} \mathrm{PO}_{4}\right)$. Calculi composed of pure struvite and those composed of only uric acid or cystine do not contain Gla. From calcium oxalate and hydroxyapatite stontes, a protein of about 17,000 daltons was obtained which contained about 40 residues of Gla per 1,000 amino acids. The amino acid composition of this protein had no apparent relationship to the Gla-containing bone protein or to the similarly-sized $F_{1}$ fragment of prothrombin which contains about 64 residues of Gla per 1,000 amino acid residues. The Gla-rich protein in calcium-containing renal stones thus may be a different Gla-containing protein. These data as well as other studies demonstrating the presence of Gla in pathologically calcified tissues not normally containing Gla suggest that the Gla-containing proteins may be of considerable pathophysiological significance.
\end{abstract}

\section{INTRODUCTION}

$\gamma$-Carboxyglutamic acid $(\mathrm{Gla})^{1}$ has recently been found in the four vitamin K-dependent blood-clotting proteins $(1-3)$, in proteins from bone $(4,5)$, and in another plasma protein, protein $\mathrm{C}$, the function of

This work appeared in abstract form: 1976. Fed. Proc. 35: 1763.

Dr. Lian is a Senior Investigator for the Arthritis Foundation.

Received for publication 3 November 1976 and in revised form 11 February 1977.

${ }^{1}$ Abbreviations used in this paper: Gla, $\gamma$-carboxyglutamic acid; SDS, sodium dodecyl sulfate. which is presently unknown (6). In proteins, this amino acid is produced by a posttranslational carboxylation of specific glutamic acid residues in the precursor protein by a vitamin K-dependent and bicarbonate ion-requiring reaction which has been studied in liver (7) and kidney (8) microsomes. The formation of Gla in the chicken bone protein is also vitamin Kdependent (9) and bicarbonate ion-requiring (10). In prothrombin, these Gla residues act as calciumbinding sites essential for the vital calcium- and phospholipid-dependent conversion of prothrombin to thrombin. If this carboxylation reaction is inhibited in vivo by coumarin-type anticoagulants or by vitamin $\mathrm{K}$ deficiency, the prothrombin protein, which is deficient in $\gamma$-carboxyglutamic acid, exhibits only weak, relatively nonspecific interaction with calcium ions, and the conversion to thrombin in the normal clotting cascade sequence is greatly retarded (11).

Since the Gla residues in the blood-clotting proteins appear to have calcium-binding properties essential for their normal physiological function, it appears possible that other proteins which are involved in other functions involving calcium ions may also contain this specific amino acid. Using a simple and reliable method developed in our laboratory for the quantitative measurement of Gla in proteins (4), we report the presence of Gla both in proteins of the organic matrix of only those renal calculi containing calcium and in certain urinary proteins.

\section{METHODS}

Renal calculi. Five types of urinary calculi, of which the major crystalline constituent (greater than 95\%) was characterized by polarization microscopy and X-ray diffraction as calcium oxalate, hydroxyapatite, magnesium ammonium phosphate (struvite), mixtures of hydroxyapatite and struvite, uric acid, and cystine, were utilized in these studies. Except for the struvite stones which were obtained 
TABLE I

Amino Acid Composition* of the EDTA-Soluble, Nondialyzable Proteins of Renal Calculi

\begin{tabular}{|c|c|c|c|c|c|c|c|}
\hline \multirow[t]{2}{*}{$\begin{array}{l}\text { Amino } \\
\text { acids }\end{array}$} & \multicolumn{2}{|c|}{$\begin{array}{l}\text { Calcium } \\
\text { oxalatet }\end{array}$} & $\begin{array}{c}\text { Hydroxy- } \\
\text { apatite }\end{array}$ & Struvite & $\begin{array}{c}\text { Apatite } \\
\text { struvite }\end{array}$ & $\begin{array}{r}\text { Uric } \\
\text { acid }\end{array}$ & Cystine \\
\hline & \multicolumn{7}{|c|}{ residues 1,000 amino acids } \\
\hline Нур & - & - & - & - & - & - & - \\
\hline Asp & 307 & 212 & 237 & 171 & 165 & 103 & 127 \\
\hline Thr\$ & 50 & 50 & 55 & 61 & 54 & 50 & 55 \\
\hline Ser§ & 78 & 76 & 63 & 109 & 78 & 61 & 97 \\
\hline Glu" & 202 & 179 & 172 & 152 & 150 & 110 & 155 \\
\hline Pro & 39 & 26 & 45 & 57 & 32 & 53 & 43 \\
\hline Gly & 60 & 82 & 55 & 111 & 107 & 217 & 96 \\
\hline Ala & 53 & 66 & 56 & 89 & 71 & 105 & 75 \\
\hline Half Cys & 4 & 9 & 15 & 3 & 11 & 14 & - \\
\hline Val & 26 & 40 & 49 & 45 & 42 & 40 & 46 \\
\hline Met & 7 & 7 & 2 & 1 & 7 & - & 1 \\
\hline Ile & 19 & 19 & 28 & 21 & 29 & 24 & 36 \\
\hline Leu & 53 & 56 & 71 & 49 & 69 & 56 & 92 \\
\hline Tyr & 20 & 27 & 20 & 16 & 33 & 35 & 26 \\
\hline Phe & 13 & 33 & 33 & 28 & 27 & 25 & 43 \\
\hline Lys & 20 & 41 & 50 & 61 & 47 & 47 & 42 \\
\hline His & 22 & 34 & 26 & 9 & 31 & 25 & 27 \\
\hline Arg & 25 & 37 & 31 & 16 & 33 & 31 & 38 \\
\hline Glađ & 25 & 23 & 25 & 0.9 & 14 & 0.7 & 0.6 \\
\hline
\end{tabular}

* Amino acid content determined by $6 \mathrm{~N} \mathrm{HCl}$ hydrolysis except for Gla.

$\ddagger$ Protein extracted from pooled stones.

$\$$ Includes $O$-phosphoserine and $O$-phosphothreonine.

"Glu content corrected by subtraction of Gla.

I Determined by alkaline hydrolysis.

from dogs, ${ }^{2}$ the rest of the material was obtained from adult human patients. In typical preparations of stone matrix protein from calcium oxalate, mixed stones of apatitestruvite, and uric acid, $25 \mathrm{~g}$ of stones was obtained by pooling stones from 10 to 15 patients. The hydroxyapatitecontaining calculi which were obtained from a single patient amounted to $37 \mathrm{~g}$ distributed among seven stones. An unusually large cystine stone weighing $160 \mathrm{~g}$ and a pool of small cystine stones from two patients were examined independently.

Preparation of the matrix proteins. The stones were ground to a powder using mortar and pestle and extracted with $0.5 \mathrm{M}$ EDTA, $\mathrm{pH} 8.0$ at $5^{\circ} \mathrm{C}$ for $48 \mathrm{~h}$, with the latter procedure repeated twice. The centrifuged supernates were dialyzed exhaustively in Spectrophor I (Bausch and Lomb, Scientific Optical Products Div., Rochester, N. Y.) against water and then freeze dried.

Hydrolysis conditions. (a) Gla content: to assay for the presence of Gla, $5 \mathrm{mg}$ of protein was hydrolyzed in $0.5 \mathrm{ml}$ of $2 \mathrm{M} \mathrm{KOH}$ in vacuo for $24 \mathrm{~h}$ in alkaline-resistant tubes (model 7280, Corning Glass Works, Corning, N. Y.). The hydrolysate was neutralized to $\mathrm{pH} 7$ with $70 \%$ perchloric acid at $0^{\circ} \mathrm{C}$ and centrifuged to remove $\mathrm{KClO}_{4}$. (b) total amino acid content: $1 \mathrm{mg}$ of protein was hydrolyzed in $1 \mathrm{ml}$ of

${ }^{2}$ Pure $\mathrm{MgNH}_{4} \mathrm{PO}_{4}$ do not exist in humans, probably because of the higher levels of calcium in human urine than in dog urine. constantly-boiling $6 \mathrm{~N} \mathrm{HCl}$ in vacuo for $24 \mathrm{~h}$ at $105^{\circ} \mathrm{C}$. (c) Phosphoserine content: for the routine detection of $O$-phosphoserine, $3 \mathrm{mg}$ of protein was hydrolyzed in $4 \mathrm{~N}$ $\mathrm{HCl}$ for $6 \mathrm{~h}$ in vacuo at $105^{\circ} \mathrm{C}(12)$. A timed series of hydrolyses (from 1 to $24 \mathrm{~h}$ ) was also carried out to determine the destruction of $O$-phophoserine under the conditions used. When these data were extrapolated to zero time, it was found that, in $4 \mathrm{~N} \mathrm{HCl}$ at $105^{\circ} \mathrm{C}$ for $6 \mathrm{~h}$, approximately $70 \%$ of the $O$-phosphoserine was recovered. Similar studies of $O$ phosphothreonine revealed that only $30 \%$ of the $O$-phosphothreonine content was recovered after similarly timed hydrolysis.

Amino acid analysis. A Beckman/Spinco model 121 amino acid analyzer (Beckman Instruments, Inc. Spinco Div., Palo Alto, Calif.) equipped with a single column $(0.28 \times 33.0 \mathrm{~cm})$ of Beckman AA-20 resin and an integrator system was used. (a) Gla program: for the complete separation of Gla from taurine and cysteic acid, a short program was run employing a stepped series $0.2 \mathrm{M}$ citrate buffer from $\mathrm{pH} 2.70$ to 3.44 . The position of Gla was determined with an authentic sample obtained from Dr. Richard Hiskey of the University of North Carolina at Chapel Hill. The amount of Gla was quantitated using the color factor for Gla obtained with the authentic compound. The content of glutamic acid was obtained by subtracting the number of Gla residues from the total number of glutamic acid residues found after hydrolysis in $6 \mathrm{~N} \mathrm{HCl}$ for $24 \mathrm{~h}$ at $108^{\circ} \mathrm{C}$. (b) Total amino acid analysis was performed using the standard Beckman program. (c) Phosphoserine program: $O$-phosphoserine and $O$-phosphothreonine were separated from cysteic acid, and taurine employing $0.2 \mathrm{M}$ sodium citrate buffer, $\mathrm{pH}$ 1.6.

Isolation of Gla and decarboxylation to glutamic acid. Alkaline hydrolysates of $25 \mathrm{mg}$ of the EDTA-soluble proteins from calcium oxalate stones with putative Gla were applied to a preparative amino acid column $(90 \times 6 \mathrm{~cm})$ containing Technicon Chromobeads type A resin (Technician Instruments Corp., Tarrytown, N. Y.) and equipped with a split stream collecting $97 \%$ in 2.5 -ml fractions and monitoring $3 \%$ by ninhydrin. The Gla was eluted with $\mathrm{pH} 2.5,0.2 \mathrm{M}$ citrate buffer and found to be in one tube. Part of the fraction was adjusted to $\mathrm{pH} 1.0$ with $1 \mathrm{~N} \mathrm{HCl}$ on ice and divided into equal aliquots which were placed in sealed ampoules and heated in a boiling water bath for $5,10,15,20$, and $40 \mathrm{~min}$. The decarboxylation reaction was stopped at the specified times by placing the sealed ampoule on ice. Each aliquot and a portion of the original fraction were analyzed for its Gla and glutamic acid contents.

Fractionation of the EDTA extract of calcium oxalate and calcium hydroxyapatite stones. $150 \mathrm{mg}$ of EDTA-extracted material from either calcium oxalate or hydroxyapatite stones were dissolved in $5 \mathrm{ml}$ of $0.05 \mathrm{M} \mathrm{NH} \mathrm{NHCO}_{3}$ buffer and applied to a Sephadex G-100 column (Pharmacia Fine Chemicals, Inc., Div. of Pharmacia, Inc., Piscataway, N. J.) $2.5 \times 90 \mathrm{~cm}$ equilibrated in $0.05 \mathrm{M} \mathrm{NH} \mathrm{NCO}_{3}$ at room temperature. The sample was eluted with the same buffer at $15 \mathrm{ml} / \mathrm{h}$ in 3-ml fractions. Each fraction was read in a Zeiss spectrophotometer (Carl Zeiss, Inc., New York) at 230 $\mathrm{nm}$. Sodium dodecyl sulfate (SDS) gel electrophoresis was performed by the method of Shapiro et al. (13). Molecular weights were determined in 10 and $12 \%$ acrylamide gels which were stained in Coomassie Blue.

Analysis of urine samples. 24-h urines were collected from three adults with no family history of renal calculi and from three patients who are recurrent stone formers. Urines were dialyzed exhaustively against water in Spectrophor I and lyophilized. The material was analyzed for Gla by $2 \mathrm{~N} \mathrm{KOH}$ hydrolysis for protein content by standard amino acid analysis. 

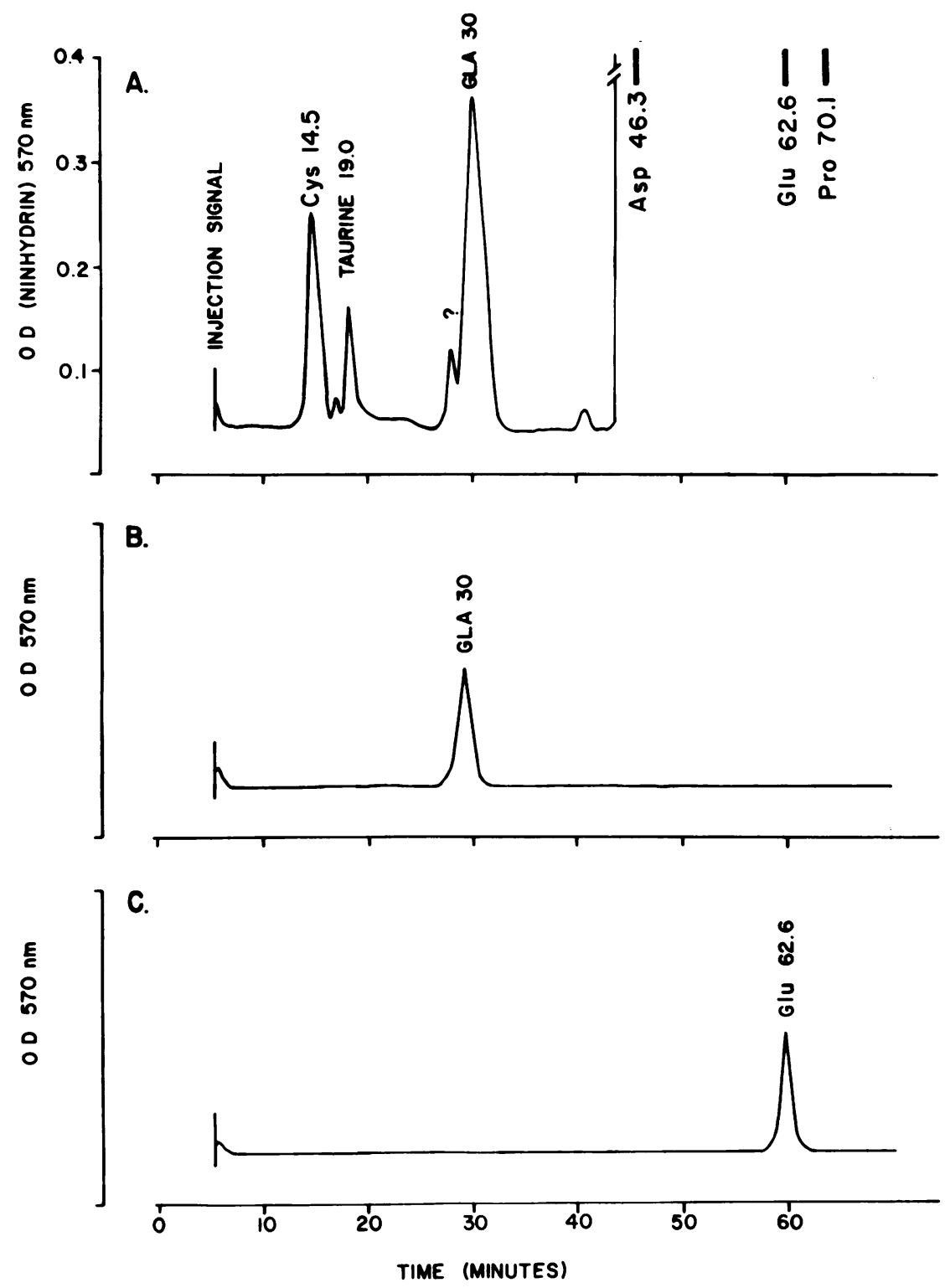

FIGURE 1 Beckman 121-M amino acid elution profiles. The initial elution buffer of $0.2 \mathrm{M}$ sodium citrate, pH 2.7 resulted in separation of Gla eluting at 30 min from cysteic acid eluting at $14.5 \mathrm{~min}$. (A) $2 \mathrm{~N} \mathrm{KOH}$ hydrolysis for $22 \mathrm{~h}$ at $106^{\circ} \mathrm{C}$ of the EDTA-soluble, nondialyzable protein from calcium oxalate stones. (B) An aliquot of the putative Gla isolated on a preparative amino acid column after alkaline hydrolysis of the EDTA extract. (C) Conversion of Gla to glutamic acid is indicated. An aliquot of the putative Gla was heated in $0.5 \mathrm{~N} \mathrm{HCl}$ for $1 \mathrm{~h}$ at $100^{\circ} \mathrm{C}$ before amino acid analysis.

\section{RESULTS}

The yield of nondialyzable extractable protein after three 48-h EDTA extractions ranged from 2.6 to $5.3 \%$ of the total dry weight of the original stone in the case of the calcium oxalate stones, $7.8 \%$ for hydroxyapatite stones, and $0.4-0.9 \%$ for pure magnesium ammonium phosphate, uric acid, cystine, and apatite-struvite stones. The amino acid composition of the EDTAsoluble, nondialyzable extracts obtained from the various calculi are shown in Table I. The nondialyzable extracts obtained from different pools of calciumoxalate stones showed varying aspartic acid contents ranging from 212 to 307 residues/1,000 total amino acid residues. The Gla content of these extracts from calcium oxalate stones ranged from 19.5 to 25 resi- 


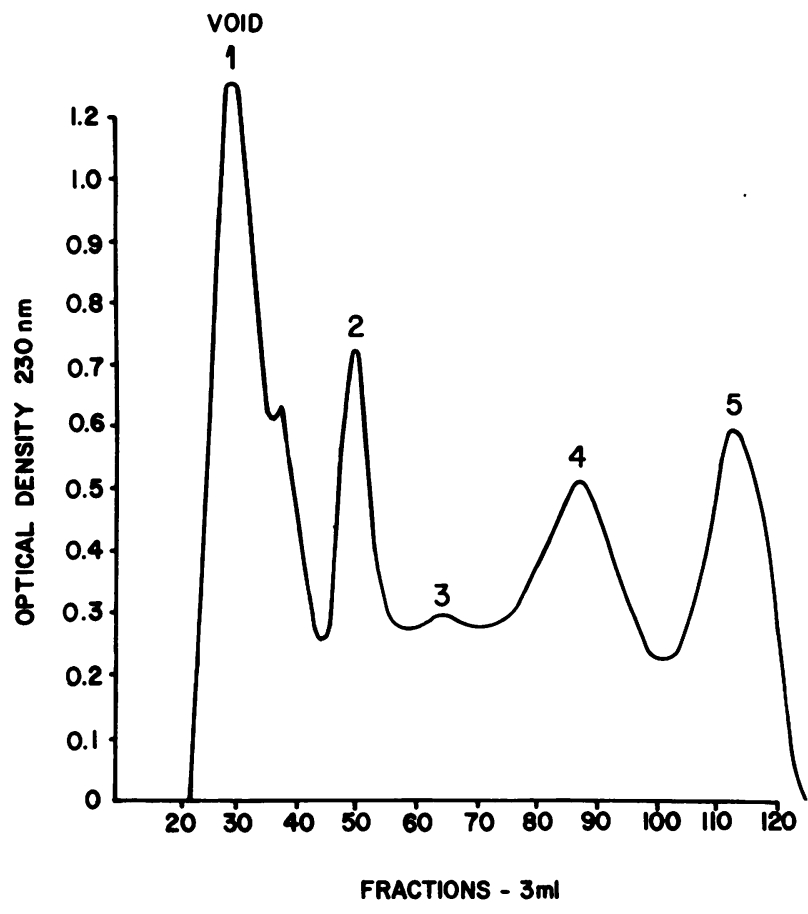

FIGURE 2 Gel filtration chromatography. $150 \mathrm{mg}$ of the EDTA extract from calcium oxalate stones was separated into five fractions on Sephadex G-100 in $0.1 \mathrm{M} \mathrm{NH}_{4} \mathrm{HCO}_{3}$ eluting with the same buffer at a flow rate of $12 \mathrm{ml} / \mathrm{h}$.

dues $/ 1,000$ total amino acid residues. The extracts obtained from apatite-struvite stones contained from 12 to 22 residues of $\mathrm{Gla} / 1,000$ total amino acid residues, whereas the EDTA extract of the hydroxyapatite stones contained 25 residues of $\mathrm{Gla} / 1,000$ amino acid residues. The uric acid stones and the cystine stone pools contained either no Gla or only trace amounts of Gla. Pure magnesium ammonium phosphate stones of canine origin were also found to contain only trace amounts of Gla $(<1$ residue $/ 1,000$ amino acids).

Fig. 1A demonstrates the ninhydrin-positive peak at the position of Gla obtained from the alkaline hydrolysate of the EDTA-soluble, nondialyzable proteins from the calcium oxalate stones. The putative Gla peak disappears if the alkaline hydrolysate is boiled at $\mathrm{pH}<1$ for $1 \mathrm{~h}$ before amino acid analysis. The identity of this peak as Gla was confirmed by isolation of a sufficient quantity of the amino acid which converted to glutamic acid when subjected to heat- and acid-catalyzed decarboxylation. The putative Gla fraction, isolated on the preparative column from a $25-\mathrm{mg}$ hydrolysate, is observed to be free from the other acidic components when chromatographed in a Beckman 121-M analyzer (Fig. 1B). When this fraction was heated to $100^{\circ} \mathrm{C}$ at $\mathrm{pH} 1.0$, it was converted only to glutamic acid (Fig. 1C).
The half-time conversion of Gla to glutamic acid under these conditions was the same $(9 \mathrm{~min})$ as found with authentic Gla.

Gel filtration of the EDTA extract from calcium oxalate stones on Sephadex G-100 yielded five fractions (Fig. 2). Different pools had similar but not identical profiles with differences observed in the relative yields of peaks 2 and 5 . The Gla-rich fraction, peak 4 , usually accounted for $25 \%$ of the protein content in the EDTA extract.

The percent protein in each fraction, its Gla, phosphoserine, and partial amino acid composition are summarized in Table II. A significant amount of $O$ phosphoserine and $O$-phosphothreonine were found in the lower molecular weight or retarded G-100 fractions. The marked destruction of $O$-phosphothreonine combined with the relatively small amount present, precluded an accurate calculation of its content. Qualitatively, it appeared to be present at a concentration less than $10 \%$ of the $O$-phosphoserine. The apparent molecular weight of the major component in each fraction is also given in Table II, and the SDS dics gels of each fraction are shown in Fig. 3. Peak 5 traveled with the buffer front and stained very poorly. The Gla-rich, peak 4 fraction (with 44 residues/1,000) has an apparent molecular weight of 17,000 daltons.

The soluble, nondialyzable proteins in the EDTA extract from hydroxyapatite stones was similarly fractionated by gel filtration on a Sephadex G-100 column. A fraction eluting in the same area as peak 4 from calcium oxalate was again found to be the Gla-rich component. Disc gel electrophoresis showed the fraction to be a protein of approximately 15,000 daltons. The protein has a slightly lower Gla content than the

TABLE II

Distribution, Molecular Weight, and Partial Amino Acid Content of the G-100 Fractions of Calcium Oxalate EDTA-Soluble Proteins

\begin{tabular}{|c|c|c|c|c|c|}
\hline & \multicolumn{5}{|c|}{ Peak } \\
\hline & 1 (Void) & 2 & 3 & 4 & 5 \\
\hline \multicolumn{6}{|c|}{ Distribution by protein } \\
\hline content, \% & 38 & 20 & 16 & 23 & 3 \\
\hline $\begin{array}{l}\text { Mol wt of major } \\
\text { component }\end{array}$ & ND* & 49,000 & 23,000 & 17,000 & ND* \\
\hline \multicolumn{6}{|c|}{$\begin{array}{l}\text { Amino acids, residues of amino acid/ } \\
1,000 \text { total amino acid residues }\end{array}$} \\
\hline Asp & 109 & 144 & 180 & 290 & 260 \\
\hline Glu & 123 & 153 & 187 & 188 & 190 \\
\hline Gla & $\mathbf{0}$ & 5 & 12 & 39 & 11 \\
\hline $\begin{array}{l}\text { O-Phospho- } \\
\text { serine }\end{array}$ & 1.5 & 4 & 10 & 13 & 9 \\
\hline
\end{tabular}

* Not determined. 


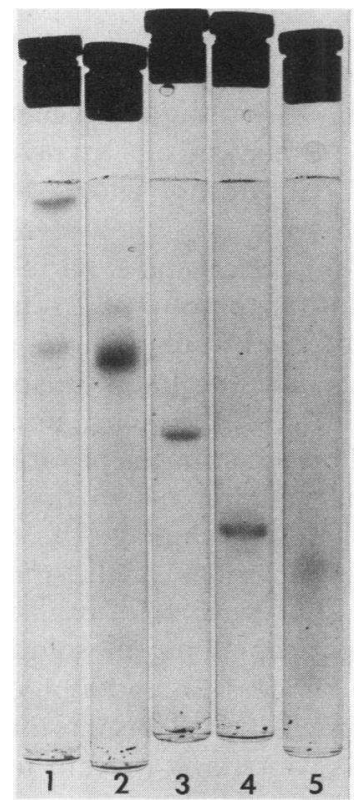

Figure 3 Dodecyl sulfate electrophoresis. $10 \%$ acrylamidedodecyl sulfate gels of the Sephadex G-100 peaks 1-5 from the fractionation of the EDTA extract from calcium oxalate stones.

calcium oxalate protein (Table III) but a strikingly similar amino acid composition. Table III compares the amino acid composition of the calcium oxalate and hydroxyapatite stone "matrix" protein with two known Gla-containing proteins of similar Gla contents: the $F_{1}$ fragment of prothrombin (residues 1-156) and the EDTA-soluble, nondialyzable Glacontaining protein obtained from chicken bone (osteocalcin).

After the identification of Gla in calcium-containing renal calculi, the nondialyzable urinary proteins from three stone patients with a history of recurrent stone disease and three normals were analyzed for Gla content. Gla was found to be present ranging from 4.3 to 6.4 residues $/ 1,000$ amino acids in the nondialyzable protein of both normal and stone-forming patients. A dog urine was similarly analyzed and contained 7.2 Gla residues/1,000 amino acids in the nondialyzable urinary proteins. Isolation of the Glacontaining urinary proteins is in progress.

\section{DISCUSSION}

In general, the overall amino acid composition of the EDTA-soluble, nondialyzable proteins associated with varying types of renal calculi is quite similar, confirming an earlier report by Spector et al. (14). These investigators also noted that there were significant differences in the amino acid composition of certain of the partially purified proteins derived from the calcium oxalate, apatite struvite, and uric acid stones, perhaps related to the differences in the structure of the crystalline component of the stones.

In the present study, another very distinct difference between the proteins derived from the various renal calculi was detected, namely, that only the proteins associated with calcium-containing calculi contained Gla. The protein in the calcium oxalate and the hydroxyapatite stones had a consistently high level of Gla, whereas the proteins associated with uric acid, cystine, and struvite did not contain Gla. The calculi composed of both struvite and hydroxyapatite contained a variable amount of Gla roughly in proportion to the percentage of hydroxyapatite present. Thus it appears that the Gla content correlates with the calcium content of the stones and not with the total

TABLE III

Amino Acid Composition of Several GLA-Containing Proteins

\begin{tabular}{|c|c|c|c|c|}
\hline \multirow[b]{2}{*}{$\begin{array}{l}\text { Amino } \\
\text { acids }\end{array}$} & \multicolumn{3}{|c|}{ Protein from } & \multirow[b]{2}{*}{$\begin{array}{c}\text { Human } \\
\text { prothrombin } \\
\mathrm{F}_{1} \text { fragment }\end{array}$} \\
\hline & $\begin{array}{l}\text { Hydroxy- } \\
\text { apatite } \\
\text { stone* }^{*}\end{array}$ & $\begin{array}{c}\text { Calcium } \\
\text { oxalate } \\
\text { stone* }\end{array}$ & $\begin{array}{l}\text { Chicken } \\
\text { bonet }\end{array}$ & \\
\hline \multicolumn{5}{|c|}{$\begin{array}{l}\text { residues of amino acid/1,000 } \\
\text { total amino acid residues }\end{array}$} \\
\hline Asp & 309 & 290 & 108 & $90 \leftarrow$ \\
\hline Thr" & 41 & 44 & 8 & $64 \leftarrow$ \\
\hline Serf & 55 & 65 & 45 & 71 \\
\hline Gluף & 190 & 188 & 134 & $84 \leftarrow$ \\
\hline Pro & 25 & 38 & 97 & 64 \\
\hline Gly & 34 & 41 & 98 & 71 \\
\hline Ala & 41 & 46 & 120 & 64 \\
\hline Cys & 3 & 7 & 3 & $64 \leftarrow$ \\
\hline Val & 37 & 29 & 56 & 57 \\
\hline Met & 15 & 12 & 2 & 6 \\
\hline Ile & 25 & 20 & 22 & 25 \\
\hline Leu & 41 & 52 & 66 & 64 \\
\hline Tyr & 37 & 27 & 51 & 26 \\
\hline Phe & 28 & 18 & 37 & 26 \\
\hline His & 18 & 24 & 19 & 13 \\
\hline Lys & 20 & 22 & 8 & 32 \\
\hline Arg & 19 & 24 & 61 & $96 \leftarrow$ \\
\hline Try** & 11 & 5 & $<1$ & 19 \\
\hline Gla** & 39 & 44 & 60 & 64 \\
\hline $\begin{array}{l}\text { O-Phospho- } \\
\text { serine }\end{array}$ & 9 & 13 & 8 & 0 \\
\hline
\end{tabular}

Arrows indicate significant differences.

* Separated from the nondialyzable proteins in the EDTA extract from hydroxyapatite and calcium renal stones by gel filtration.

\$ Separated by gel filtration on Sephadex G-100.

$\$$ Magnusson et al. (3).

"Includes $\boldsymbol{O}$-phosphothreonine.

I Corrected by subtraction.

** Determined by alkaline hydrolysis. 
content of matrix protein or with the presence of Gla in the urine. The analysis of the pure struvite $\left(\mathrm{MgNH}_{4} \mathrm{PO}_{4}\right)$ stones, such as are found in dogs (and not in humans), shows an absence of Gla which is consistent with the above speculation. Although this is a cross-species comparison, we have shown that dog urine contains Gla (vide infra).

The presence of Gla in calcium-containing stones is consistent with the known calcium-binding properties of protein-bound Gla $(1,2)$. The additional presence of $O$-phosphoserine in the proteins of these renal stones may not only be important in the binding of the calcium ions but also in fixing their stereochemical configuration, especially if the carboxyl groups are in close juxtaposition to the $O$-phosphoserine residues as they are in the enamel proteins (15).

To date, Gla has been identified as a component of the vitamin K-dependent blood-clotting factors (3), in a plasma protein, protein $\mathrm{C}$ (6), and in the EDTAsoluble, nondialyzable proteins of chicken and bovine bone $(4,5)$. The major protein components of the calcium-containing stones is relatively rich in this unique calcium-binding amino acid, to the same degree as the $F_{1}$ fragment from prothrombin (64 residues/1,000) (3) and the protein from bone (60 residues $/ 1,000)$. A comparison of the amino acid composition of the purified Gla-containing protein of renal calculi with the other known Gla-containing proteins, however, shows marked differences in the amino acid composition, particularly in the aspartic acid and arginine content. This makes it highly unlikely that the Gla-containing protein(s) of renal calculi represent any of the known Gla-containing proteins such as prothrombin or the bone protein. Thus it seems most likely that the Gla-containing proteins extracted from renal calculi represent still another distinct class of proteins containing Gla.

Although the preliminary results have demonstrated the presence of Gla-containing protein(s) in the urine of normal and stone-forming patients, the relationships among the proteins excreted in the urine, the known serum and bone proteins, and the proteins obtained from renal calculi are unclear. In this regard, the recent finding that kidney microsomes synthesize a protein containing Gla is of great significance (8).

It is not possible at this time to ascribe a function to the Gla-containing proteins of renal calculi. Glacontaining proteins have been detected in the ectopic calcifications of soft tissues which do not normally contain Gla (16). In both this instance and in the case of the Gla-containing proteins associated with the bone matrix, it is not clear whether the protein is associated with the initiation of calcification, whether it represents an inhibitor of mineralization, or whether it arises by virtue of the fact that the Gla-containing proteins are adsorbed to the calcium-containing calculi much as they may be fractionated on columns of hydroxyapatite due to the binding of the Gla residues to calcium (4). On the other hand, although the exact biochemical mechanisms involved in the formation of renal calculi are not known either in general or for any of the specific types of renal stone, it is clear from both theoretical and experimental considerations that a solution to solid-phase transformation is unlikely to occur only by simple homogeneous nucleation (17). It has not yet been established whether the first fragments of the solid mineral phase are initially formed on the surfaces of various microscopic or ultrastructural components in the kidney, as suggested by Caulfield and Schrag (18), or are nucleated in solution by interactions of the renal calculi components $\left(\mathrm{Ca}^{++}, \mathrm{PO}_{4}{ }^{\equiv}\right.$, uric acid, oxalate) with specific macromolecular components in solution (19), but in any event, the process is undoubtedly initiated by heterogeneous nucleation. Thus it is tempting to speculate that the Gla-containing protein may serve as the nucleation substrate, although an equally plausible argument can be advanced that they function in just the opposite way. Similar considerations (16) have evolved concerning the possible role of the phosphoproteins in the initiation of calcification in enamel (15), bone (20), and dentin (21).

Further investigations on the nature of the Glacontaining protein of renal calculi, their site of synthesis, their $\mathrm{Ca}^{++}$-interaction properties, and the number, configuration, and interaction properties of the bound calcium ions (17), as well as their relationship to the proteins in the urine containing Gla, may shed light on their physiological role.

\section{ACKNOWLEDGMENTS}

The authors wish to thank Dr. P. Hauschka and Dr. S. Krane for valuable discussions and K. Heroux and M. Farmer for expert technical assistance.

This work was supported in part by National Institutes of Health grants AM-76001, AM-03564, AM-04501, AM16754, and AG-376 and by a grant from the New England Peabody Home for Crippled Children, Inc.

\section{REFERENCES}

1. Nelsestuen, G. L., and J. W. Suttie. 1973. The mode of action of vitamin $\mathrm{K}$. Isolation of a peptide containing the vitamin K-dependent portion of prothrombin. Proc. Natl. Acad. Sci. U. S. A. 70: 3366-3370.

2. Stenflo, J., P. Fernlund, W. Egan, and P. Roepstorff. 1974. Vitamin $K$ dependent modifications of glutamic acid residues in prothrombin. Proc. Natl. Acad. Sci. U. S. A. 71: 2730-2733.

3. Magnusson, S., T. E. Petersen, L. Sottrup-Jensen, and H. Claeys. 1975. Complete primary structure of prothrombin: Isolation, structure and reactivity of ten carboxylated glutamic acid residues and regulation of prothrombin activation by thrombin. In Proteases and 
Biological Control. E. Reich, D. B. Rifkin, and E. Shaw, editors. Cold Spring Harbor Laboratories, Cold Spring Harbor, N. Y. 123-149.

4. Hauschka, P. V., J. B. Lian, and P. M. Gallop. 1975. Direct identification of the calcium-binding amino acid, $\gamma$-carboxyglutamic acid, in mineralized tissue. Proc. Natl. Acad. Sci. U. S. A. 72: 3925-3929.

5. Price, P. A., A. S. Otsuka, J. W. Poser, J. Kristaponis, and N. Raman. 1976. Characterization of a $\gamma$-carboxyglutamic acid-containing protein from bone. Proc. Natl. Acad. Sci. U. S. A. 73: 1447-1451.

6. Stenflo, J. 1976. A new vitamin K-dependent protein. Purification from bovine plasma and preliminary characterization. J. Biol. Chem. 251: 355-363.

7. Esmon, C. T., J. A. Sadowski, and J. W. Suttie. 1975. A new carboxylation reaction. The vitamin $\mathrm{K}$-dependent incorporation of $\mathrm{H}^{14} \mathrm{CO}_{3}^{-}$into prothrombin. J. Biol. Chem. 250: 4744-4748.

8. Hauschka, P. V., P. A. Friedman, H. P. Traverso, and P. M. Gallop. 1976. Vitamin K-dependent $\gamma$-carboxyglutamic acid formation by kidney microsomes in vitro. Biochem. Biophys. Res. Commun. 71: 1207-1213.

9. Hauschka, P. V., M. L. Reid, J. B. Lian, P. A. Friedman, and P. M. Gallop. 1975. Probable vitamin Kdependence of $\gamma$-carboxyglutamic formation in bone. Fed. Proc. 35: 18. (Abstr.)

10. Lian, J. B., P. V. Hauschka, M. J. Glimcher, and P. M. Gallop. 1976. Incorporation of ${ }^{14} \mathrm{CO}_{2}$ into embryonic chick bone and identification of $\gamma$-carboxyglutamic acid. Trans. 22nd Annu. Meet. Orthop. Res. Soc. 1: 176. (Abstr.)

11. Esmon, C. T., J. W. Suttie, and C. M. Jackson. 1975. The functional significance of vitamin $\mathrm{K}$ action. Difference in phospholipid binding between normal and abnormal prothrombin. J. Biol. Chem. 250: 4095-4099.
12. Veis, A., A. R. Spector, and H. Zamoscianyk. 1972. The isolation of an EDTA-soluble phosphoprotein from mineralizing bovine dentin. Biochim. Biophys. Acta. 257: 404-413.

13. Shapiro, A. L., E. Viñuela, and J. V. Maizel, Jr. 1967. Molecular weight estimation of polypeptide chains by electrophoresis in SDS-polyacrylamide gels. Biochem. Res. Commun. 28: 815-820.

14. Spector, A. R., A. Gray, and E. L. Prien, Jr. 1976. Kidney stone matrix: differences in acid protein composition. Invest. Urol. 13: 387-389.

15. Seyer, J., and M. J. Glimcher. 1969. The amino acid sequence of two o-phosphoserine containing tripeptides isolated from the organic matrix of embryonic bovine enamel. Biochim. Biophys. Acta. 181: 410-418.

16. Lian, J. B., M. Skinner, M. J. Glimcher, and P. M. Gallop. 1976. The presence of $\gamma$-carboxyglutamic acid in the proteins associated with ectopic calcification. Biochem. Biophys. Res. Commun. 73: 349-355.

17. Glimcher, M. J. 1976. Composition, structure, and organization of bone and other mineralized tissues and the mechanism of calcification. Handb. Physiol. 7(Sect. 7, Endocrinology): 25-116.

18. Caulfield, J. B., and P. E. Schrag. 1964. Electron microscopic study of renal calcification. Am. J. Pathol. 44: 365-381.

19. Boyce, W. H. 1968. Organic matrix of human urinary concretions. Am. J. Med. 45: 673-683.

20. Spector, A. R., and M. J. Glimcher. 1972. The extraction and characterization of soluble anionic phosphoprotein from bone. Biochim. Biophys. Acta. 263: 593603.

21. Butler, W. T., J. E. Finch, Jr., and C. V. DeSteno. 1972. Chemical characterization of proteins in rat incisors. Biochim. Biophys. Acta. 257: 167-171. 